\title{
Multi-Needs for Multi-Screening: Practices, Motivations, and Attention Distribution
}

\section{Patrícia Dias ${ }^{1}$ Javier Serrano-Puche ${ }^{2}$}

Recibido: 07/05/2018

Aprobado por pares: 18/12/2018
Enviado a pares: $21 / 09 / 2018$

Aceptado: 17/01/2019

DOI: 10.5294/pacla.2020.23.1.2

To reference this paper / para citar este artículo / para citar este artigo

Dias, P. \& Serrano-Puche, J. (2020). Multi-needs for multi-screening: Practices, motivations and attention distribution. Palabra Clave, 23(1), e2312. D0I: https://doi. org/10.5294/pacla.2020.23.1.2

\section{Abstract}

Multi-screening is an emergent but fast-growing and fast-changing practice, evolving along with the technologies that mediate it. This article presents a study on multi-screening, i.e., simultaneously or sequentially engaging with more than one screened-media. Based on the uses and gratifications theory, our study focused on the most common multi-screening scenario - engaging with the smartphone while watching TV-in order to explore triggers, motivations, gratifications, and attention distribution. The methodology is qualitative in nature, including ethnographic journals and follow-up interviews to a sample of 30 young adults, and the data was collected in Portugal and Spain. The activities performed on each device are usually disconnected and motivated by the need to enhance the entertainment afforded by the TV or to obtain a sense of efficiency. The attention is distributed in alternated periods, and the smartphone has a greater ability of demanding attention and retaining the engagement.

1 https://orcid.org/0000-0001-7948-4439. Universidad Católica de Portugal, Portugal. pdias@fch.lisboa.ucp.pt

2 https://orcid.org/0000-0001-6633-5303. Universidad de Navarra, España. jserrano@unav.es 


\section{Keywords (Source: Unesco Thesaurus)}

Television; mobile phones; cellphones; smartphones; attention; multi-screening; qualitative analysis.

\section{Necesidades múltiples para pantallas múltiples: prácticas, motivaciones y distribución de atención}

\section{Resumen}

El multi-screening o "pantallas múltiples" es una práctica emergente pero de crecimiento y cambio rápidos que evoluciona junto con las tecnologías que la median. Este artículo presenta un estudio sobre el multi-screening, en otras palabas, el uso simultáneo y secuencial de más de una pantalla. Con base en la teoría de usos y gratificaciones, nuestro estudio se centró en el escenario de multi-screening más común - el uso del teléfono inteligente junto con la televisión - para explorar los factores desencadenantes, las motivaciones, las gratificaciones y la distribución de la atención. La metodología es cualitativa e incluye revistas etnográficas y entrevistas de seguimiento a una muestra de 30 adultos jóvenes, y los datos se recopilaron en Portugal y España. Las actividades realizadas en cada dispositivo no suelen estar relacionadas y normalmente están motivadas por la necesidad de mejorar el entretenimiento que ofrece el televisor o de tener una sensación de eficiencia. La atención se distribuye en períodos alternados, y el teléfono inteligente tiene una mayor capacidad de exigir y mantener la atención.

\section{Palabras clave (Fuente: tesauro de la Unesco)}

Televisión; teléfono móvil; celular; teléfono inteligente; multi-screening, análisis cualitativo. 


\section{Necessidades múltiplas para telas múltiplas: práticas, motivações e distribuição de atenção}

\section{Resumo}

O multi-screening ou "telas múltiplas" É uma prática emergente, mas de rápido crescimento e mudança que evolui junto com as tecnologias que a medeiam. Este artigo apresenta um estudo sobre o multi-screening, ou seja, o uso simultâneo e sequencial de mais de uma tela. Com base na teoria dos usos e gratificações, nosso estudo se concentrou no cenário de multi-screening mais comum - o uso do smartphone junto com a televisão - para explorar os gatilhos, as motivações, as gratificações e a distribuição de atenção. A metodologia é qualitativa e inclui revistas etnográficas e entrevistas de acompanhamento com uma amostra de 30 jovens adultos, sendo os dados recolhidos em Portugal e na Espanha. As atividades realizadas em cada dispositivo geralmente não estão relacionadas e são motivadas pela necessidade de melhorar o entretenimento oferecido pela televisão ou de ter uma sensação de eficiência. A atenção é distribuída em períodos alternados, e o smartphone tem maior capacidade de exigir e manter a atenção.

\section{Palavras-chave (Fonte: tesauro da Unesco)}

Televisão; telefone celular; celular; telefone inteligente; multi-triagem, análise qualitativa. 


\section{Introduction}

In contemporary society, portable and personal digital devices, such as smartphones and tablets (and other wearables in a near future), are fully integrated in households, purses, and pockets (Shin, An, \& Kim, 2015). These digital, personal media interact with the previous mass media, driving innovative and convergent practices (Cooper \& Tang, 2009). One example of such practices is second screening or multi-screening, which is the simultaneous or sequential use of more than one screened device. The most common combination of screens is using the smartphone while watching television (Google, 2012). This emergent practice is relatively widespread and "feels natural" to users-mostly because the smartphone has become so important in daily life that it has been conceptualized by several authors as an extension or prosthesis of the user (Fortunati, 2002; Katz, 2006; Dias, 2008; Serrano-Puche, 2015). Our study sets out to further investigate the motivations that drive this practice, its different forms and variations, and its consequences on the way users perceive and experience it.

\section{Multi-Screening as an Emergent Practice and Underlying Debates}

\section{The redefinition of second screening as multi-screening}

When researching multi-screening, one of the challenges we find is defining the phenomenon studied, as there are several options in the literature, each with different nuances and implications.

A first distinction to consider is between multi-screening and multi-tasking. While multi-tasking describes any set of more than one task performed simultaneously, multi-screening is a more restrict way of multi-tasking that involves the simultaneous use of at least two screened devices.

A second distinction is between the approach of media studies to this phenomenon and others that come from more technical fields. The earliest definition of this phenomenon is "second screening," from computer engineering, which refers to connecting two or more computer screens to the 
same desktop or laptop. It was later applied to using other screened-devices, such as the laptop or the mobile phone while watching television and to technological innovations such as the Smart TV. The term was adopted in media studies with a focus on audiences or users' practices, instead of technological breakthroughs (Giglietto \& Selva, 2014).

Third, and already within media studies, it is important to delimit boundaries regarding other core phenomena to the field, such as cross-platform or cross-media, as well as transmedia. While cross-media refers to the circulation of content between different platforms and the combinations and choices of users in their media diet (which may include simultaneous use of more than one screened media) (Kim, 2014), transmedia highlights the synergies resulting from an integrated or holistic approach to media production and consumption (Jenkins, 2010; Evans, 2011).

Finally, it is important to address the debates underlying similar terms. One of such debates is about attention distribution between the different screened media: While the early use of second screening elects the TVset as the main focus of attention, findings question such preponderance. Smartphones and tablets have replaced mobile phones and laptops as the main companions for watching television, and are often the focus of attention while the TV fades into the background (Giglietto \& Selva, 2014). Dual screening is an alternative for not assuming the preponderance of one medium over the other (Chun, Lee, \& Kim, 2012; Vaccari, Chardwich, \& O'Loughlin, 2015). Multi-screening is another alternative (Phalen \& Ducey, 2012; Lin, 2013; Van Cauwenberge, Schaap, \& Van Roy, 2014). Another debate is about the process of articulating the different screened-media. The initial notion of second screening only considered simultaneous use, but the broader definition of multi-screening includes simultaneous, sequential and intercalary uses (Van Cauwenberge, et al., 2014; Vaccari, et al., 2015). There is also an underlying discussion about the relationship between the activities performed on each media. The earliest research talks about social TV, referring to using other screened devices while watching television for interacting with others (Ducheneaut, Moore, \& Oehlberg, 2008). Through the synchronized use of social media platforms, such as Twitter 
and Facebook, or Instant Messaging (IM) apps such as WhatsApp, mobile devices add a social layer to watching television, usually commenting about live events or interacting within fandom communities (Lochrie \& Coulton, 2012; Buschow, Schneider, \& Ueberheide, 2014; D’heer \& Verdegem, 2015; Vergeer \& Franses, 2016; Gil de Zuñiga, Garcia-Perdomo, \& McGregor, 2015). But users also engage in conversations that are not related to TV content, but simply happen simultaneously. Haridakis and Hanson (2009) suggested the use of the term co-viewing to describe this, referring to the interaction between two or more people watching TV together. Multi-screening is, again, a broader term, encompassing other activities beyond social interactions, such as searches, purchases, gaming, reading, information, and others (Phalen \& Ducey, 2012; Lin, 2013; Van Cauwenberge et al., 2014).

In our research, we adopt the broader perspective conveyed by the term multi-screening as a framework for exploring its underlying debates, such as attention distribution and the relationship between the activities performed in the different media.

\section{Multi-screening practices and motivations}

Multi-screening practices are extremely varied, as they may include different activities on diverse screened-media, and they may be simultaneous, sequential or intercalary.

Industry reports show that the average time spent watching TV has decreased while the time spent using apps has increased. However, they reiterate the relevance of combining video content with other activities in digital environment (Google, 2012; Microsoft, 2013; Nielsen, 2015). A study on a global scale from Google (2012) shows that the most frequent combination of devices in multi-screening situations is using the smartphone while watching TV (this practice was frequent for about $50 \%$ of the sample). A more recent global scale report by Nielsen (2015) states that about half of the TV viewers engage in social TV practices, participating in conversations about TV content on social media. But other practices are also identified, such as searching (related and unrelated to TV content), gaming, checking notifications, working, and reading. Smith and Boyles (2012) 
suggest a categorization for organizing these practices: If the activities being performed on the smartphone are related to the content being watched on TV, they describe it as connected viewing, and the contrary is distracted viewing. According to their research in the United States, connected viewing is more frequent, but contrary results have been found in different contexts (e.g., D’heer, Courtois, \& Paulussen, 2012; Dias, 2016). Our research contributes to this debate by tackling our first research question: What are the activities most frequently performed in mobile devices while watching TV, and are they more frequently related or unrelated to TV content?

However, the main focus of our study is uncovering the motivations behind multi-screening practices. After a literature review on how and why audiences select and engage with media, Cooper and Tang (2009) identify two main approaches: theories centred in individual characteristics of the viewer or user, and theories focused on contextual variables and broader trends. Within this second category, Shin (2013) refers to usability and diffusion factors, adoption patterns, and policy and managerial implications. The first category, particularly the Uses and Gratifications Theory (U\&G), first formulated by Katz, Blumler, and Gurevitch (1974), is a relevant framework to explore how and why each audience member choses different devices and types of content. However, there are some inconsistencies to be addressed. Firstly, U\&G states that media are constantly competing for the audience's time, attention and preference, which leads to the fact that the adoption of new media usually happens at the expense of previous media (Rubin, 1994), but in the case of multi-screening, users are combining media instead of choosing between them. Second, U\&G traditionally relies on quantitative methods as surveys that provide self-reported data, but qualitative approaches may provide richer insights (Wei, 2008). Third, this originally generic theory was later applied to specific media, such as the television, the internet and the mobile phone, and even to specific features of these media (e.g., SMS, apps) and specific platforms (e.g., Facebook, Twitter) (e.g., Joison, 2008; Ho \& Syu, 2010; Quan-Haase \& Young, 2010), but there are also alternative views of the contemporary media landscape as complex, populated and convergent, calling for more holistic approaches (D’heer et al., 2012). 
Looking at research on the motivations for multi-screening, one of the issues under debate is whether the uses and gratifications traditionally associated to television - information and entertainment (e.g., Rubin, 1994; Han \& Lee, 2014) —are also the drivers for this practice, or if there are new motivations. Entertainment is found as a relevant use and gratification in most research (Ferguson \& Perse, 2000), but a significant strand of literature adds a new category: "social needs," such as connectivity and sense of belonging to a community (Ho \& Syu, 2010; Quan-Haase, 2010; Serrano-Puche, 2016). The studies on social TV claim that engaging in social interaction (about the TV content or not) is the main motivation driving multi-screening practices (e.g., Shin, Shin, Choo, \& Beom, 2011; Lee, 2013; Weeks \& Holbert, 2013; D’heer \& Courtois, 2014; Cameron \& Geidner, 2014; Buschow, Schneider, \& Ueberheide, 2015; Simons, 2015; Rossi \& Giglietto, 2016). However, some studies counter-argue that multi-screening may encompass such a diversity of activities that it is not viable to agree on a single categorization (Han \& Lee, 2014; Kramer, Winter, Benninghoff, \& Gallus, 2015). A smaller strand of research also refers that multi-screening is generally connected to a sense of fulfilment derived from being able to do more than one thing at the same time (Wang \& Tchernev, 2012; Lee \& Shin, 2014), highlighting "efficacy" or "efficiency" needs as another possible motivation.

Another question discussed in the literature is whether uses and gratifications are associated to media or to content. On the one hand, research focused on TV content has uncovered diverse motivations for multi-screening (Gil de Zuñiga, et al., 2015; Jensen, 2016); on the other hand, research on different social media platforms during multi-screening activities has uncovered more specific platform-associated uses and gratifications - for instance, multi-screening on Twitter is driven by information seeking while WhatsApp responds to the need to belong (Han \& Lee, 2014; Kramer et al., 2015).

Our second research question addresses these core debates in the field: What are the main motivations behind multi-screening practices (information, entertainment, sociability, efficacy or other) and are more 
related to media (TV, smartphones, tablets), platforms (social media, email, instant messaging, searches, etc.) or content (TV genres, types of online content, etc.)?

\section{Attention-distribution during multi-screening}

Watching TV is usually the first activity users engage with and their main focus of attention (which is why these practices were originally labelled "second screening"). The main triggers identified in the literature for multi-screening behaviour are either embedded in TV content-which usually leads to "connected viewing" - and stimuli from the smartphonewhich are more associated to "distracted viewing" (Smith \& Boyles, 2012) - . Levinson (2004) observed that a mobile phone ringing or vibrating is an intrusive, interruptive and irresistible stimulus. Ling (2004) adds that the mobile phone usually predominates over other activities, even face-to-face interaction. Thus, the redefinition of terminology from second screening to multi-screening reflects this underlying debate about attention distribution and media predominance.

Dutta-Bergman (2004) identifies two different roles that the smartphone may play regarding the TV: It may be a complement, adding components or features to the experience of watching TV (usually in disconnected uses); or it may be a companion, enhancing the experience of watching TV (usually in connected uses).

An underlying assumption of this debate is considering attention as a prerequisite for deeper engagement, which has also been described with varied terminology — apprehension, understanding, immersion, absorption, recognition, and recall (McNiven, Krugman, \& Tinkham, 2012). Another one is that the contemporary media landscape is causing cognitive changes that entail deep transformations in the production, distribution and reception systems, impacting content, business and cognitive skills (Pérez-Tornero, 2008; Jenkins, 2010; Van Cauwenberge, d'Haenens, \& Beentjes, 2015). Also, there is no agreement in the literature about how attention (and engagement) can be measured: Methods are as diverse as experiments, observation, surveys, interviews, self-reported data, and triangulating different 
methods; recall and memory have been used as main criteria to measure attention (McCreery \& Krugman, 2015).

Concerning attention distribution, research on television has shown that bigger screens and proximity to the TV-set enhance attention (Lombard, Ditton, Grabe, \& Reich, 1997; Reeves, Lang, Kim, \& Tatar, 1999). These results are coherent with the "second screen" perspective, which claims that the bigger screen, the TV, retains attention for about $70 \%$ of the time in multi-screening situations, regardless of TV content (McCreery \& Krugman, 2015). Also, the main triggers for shifting attention are "push" stimuli from mobile devices (that attract attention) or advertising on TV (that cause boredom and distraction) (Holmes, Josephson, \& Carney, 2012). Studies that compared the performance of different activities on mobile devices (relevant and irrelevant, i.e., connected and distracted) also didn't find differences in attention distribution. However, the control group that didn't multi-screen showed higher recall and comprehension of the content (Van Cauwenberge, Schaap, \& Van Roy, 2014). Research has also compared sequential and simultaneous multi-screening situations, and while no differences were found in attention distribution and cognitive apprehension, there are very different emotional effects: Simultaneous use caused higher anxiety, while sequential use led to stronger competence beliefs (Shin, An, \& Kim, 2015). An experiment by Van Cauwenberge, d'Haenens, and Beetjes (2015) found that users show higher recall and comprehension of news content presented on tablets if these are structured and formatted according to what is usual on smartphones, instead of computer screens, showing that frequent and intense smartphone use bears weight in shaping our media use and cognitive structures.

Our research also contributes to this discussion with our final research question: How is attention distributed during multi-screening situations? Our focus on this process includes the goals of identifying the attention shifting triggers, of determining whether this process is more often simultaneous or sequential, and of which (if any) of the media actually predominate over the other. 


\section{Methodology}

\section{Research questions}

Taking into account the debates and the calls for further research presented in the literature review, our research was designed with an interpretivist approach following Maxwell (1996), aimed at answering the following questions:

1. What are the activities most frequently performed in mobile devices while watching TV? And are such activities "connected" or unrelated?;

2. What are the most influential motivations for multi-screening (information, entertainment, sociability, efficacy, others)? And are they related to media, platforms, content?;

3. How is attention distributed during multi-screening (addressing attention shifting triggers, if the process is simultaneous or sequential, and if any medium predominates)?

\section{Methods and limitations}

Multi-screening is a complex, recent and diverse phenomenon, and our study is exploratory, adopting a qualitative approach (aiming at uncovering relevant insights and trends, and not generalizable findings). One of the challenges we faced in our research design was selecting a multi-screening setting for studying. Drawing on the literature, we decided to focus on the most common multi-screening binomial: using the smartphone while watching TV (Google, 2012; Nielsen, 2015; Guerrero, Diego, \& Kimber, 2017).

Concerning data collection, we wanted to triangulate the self-reported discourses of participants with information that we could observe directly, but without researchers being present in order to avoid biasing the participants' behaviour. We used ethnography (Hammersly \& Atkinson, 2007) and created a template for an ethnographic journal that we asked our participants to fill in while they watched television for two different periods longer than one hour. Participants had to insert a new entry to the template every time they used a portable device while they were watching TV, and they had to register the time, the TV content that they were watching 
and the activity that they performed on the portable device. In addition, we asked them to take photos of the TV-set screen and to take screenshots of the portable device for each entry. Participants were asked to share all these data with researchers via email. We acknowledge the limitations in this method: It is intrusive, as it requires active participation during a leisure moment; it requires the deliberate interruption of the phenomenon being studied for data registration; it relies on self-reporting, which can entail recall errors and self-regulation and filtering of the data provided. However, video recording and app usage recording was much more privacy-intrusive, it raised ethical issues, and it was more difficult to find volunteer participants. In addition, these ethnographic journals afforded unique insights about the frequency of multi-screening, the triggers for such actions, and the activities performed in each of the devices.

We addressed the aforementioned limitations by triangulating the data of the ethnographic journals with follow-up interviews with each of the participants. We used a semi-structured script focusing on uses and gratifications (Brinkman \& Kvale, 2014) and added personalized questions according to the data provided.

For data analysis, we used thematic coding (Boyatzis, 1998) and qualitative comparative analysis (Ragin, 2014) to create an anonymised database. We developed out thematic coding categories drawing on our research questions and findings from previous research — for example, considering the findings within $U \& \mathrm{G}$ about the motivations for multi-screening and resulting gratifications, we defined as coding categories: information, entertainment (e.g., Rubin, 1994; Ferguson \& Perse, 2000; Han \& Lee, 2014), sociability (Ho \& Syu, 2010; Quan-Haase, 2010; Shin, Shin, Choo, \& Beom, 2011; Lee, 2013; Weeks \& Holbert, 2013; D’heer \& Courtois, 2014; Cameron \& Geidner, 2014; Buschow, Schneider, \& Ueberheide, 2015; Simons, 2015; Rossi \& Giglietto, 2016; Serrano-Puche, 2016), and efficiency (Wang \& Tchernev, 2012; Lee \& Shin, 2014). Later, using verbatim transcripts of the interviews, we identified other emerging relevant themes - in the case of U\&G, two categories emerged-speed and safety. We created a database with all the categories and coded excerpts of the interviews. Finally, 
we created a qualitative comparative analysis (QCA) grid including sociodemographic features, technological features, uses and gratifications, and attention distribution, and filled it using data from both the ethnographic journals and the interviews.

\section{Sampling and sample}

We looked for participants that fit into the "multi-screener" profile identified by previous research (Smith \& Boyles, 2012; Microsoft, 2013; Dias \& Teixeira-Botelho, 2016) — between 18 and 25 years old, urban, tech-savvy, and with higher education. We selected a convenience sample among volunteer university students, using our personal contacts and also a general email that was sent to students via our research centres. We were careful to obtain a gender balance in the sample and also diversity in education fields. Also, we asked the first volunteers to help us find more participants among their acquaintances. We selected a group of 15 participants in Lisbon, Portugal, and another group of 15 participants in Pamplona, Spain.

Although we have conducted a comparative study, our findings did not reveal significant differences concerning our research questions. As a consequence, we chose not to focus on a thorough comparative discussion of our findings (only mentioning the most relevant differences found), but rather in discussing them in relation to our research questions and the literature review.

\section{Findings and Discussion}

\section{Mobile activities during multi-screening}

In our sample, we registered a total of 309 multi-screening instances during two evening periods of about one hour each. The average was of 5.15 multi-screening instances per participant, showing that using mobile devices while watching television is relatively frequent. The most common combination of screened devices was watching video content on the TVset and using the smartphone, but there were 12 cases that used the laptop to watch TV content. 
Concerning the activities performed in each of the devices, our QCA shows that viewers in our sample watch mostly movies and series on the $\mathrm{TV}$-set/laptop. This type of content is not watched live as viewers play recorded or downloaded content to their convenience. Participants only follow live TV broadcasting for specific content, namely news, and sports. While watching $\mathrm{TV}$, the most frequent activities performed in the smartphone are communicating in Instant Messaging apps (mostly WhatsApp but also Facebook Messenger) and browsing social networks (Instagram, Facebook, and SnapChat). Other activities reported, although less frequent, were searches, browsing branded apps (mostly fashion), and using utilities such as checking time, weather, and calendars.

Although TV-watching and online social interaction are a frequent combo in our sample, these activities are usually unrelated. Our findings are opposite to the notion of "social TV," which poses that connected uses of different screened-media are the most common multi-screening patterns (e.g., Smith \& Boyles, 2012; Nandakumar \& Murray, 2014; Weeks \& Holbert, 2013; D’heer \& Verdegem, 2015; Rossi \& Giglietto, 2016). The exploratory and qualitative nature of our study does not sustain generalized claims, but our findings are consistent with other studies, which have also reported a predominance of unrelated uses (D'heer et al., 2012; Dias, 2016).

The most common "connected viewing" practice was commenting on instant messaging (IM) apps (mostly WhatsApp) with friends about content that was being watched on TV (21 instances). This usually happened during live sports broadcasting, but there were also cases of friends making arrangements to watch the same movie or series at the same time in order to comment about it. Other related activities sporadically reported were searching on the online database, IMDb, about the movie one is watching ( 1 instance), searching on Google about a product seen on a series ( 1 instance), checking an app for placing bets in sports during sports events broadcasted live ( 1 instance).

In the interviews, we tried to explore how the participants perceived and explained their multi-screening practices, namely the predominance of 
distracted viewing and, building on previous research (e.g., Weeks \& Holbert, 2013; Lee, 2013; Gil de Zuñiga et al., 2015), the observation of an association between connected viewing and live TV broadcasting.

The smartphone keeps me company, not just when l'm watching TV, but in any activity, throughout the day. It's as if I had my friends and family in my pocket and I can talk to them all the time. (PT4)

I like to comment about what I'm watching on TV, let's imagine a soccer match. But that only makes sense if you comment with friends that are watching the same, right? It makes me feel part of a group, it's a shared experience. (ES3)

Although each of these quotes refers to different types of multi-screening, PT4 talks about distracted viewing, and ES3 comments on connected viewing, they point to the same reason: The smartphone affords what Katz and Aakhus (2002) have described as a "perpetual contact," that is, an ongoing connection to others that affords a sense of belonging and company.

\section{Motivations for multi-screening}

Multi-screening is "natural" for our interviewees, something that they do automatically, and thus they haven't given much thought to the motivations behind such behaviour, as they express in the following quotes:

Without realizing, we have one hand on the remote and the other sliding through the smartphone screen. Sometimes we don't even know what brings us to do this, it is something involuntary. (PT1)

It's almost automatic [using the smartphone while watching TV]. It's like we were born doing it. [laughter] (PT2)

Nevertheless, we asked them in the interviews to make an effort in order to reflect upon and identify the triggers and motivations that drive them to it (uses) and the benefits or satisfaction that they obtain from it (gratifications).

In Table 1 we present an overview of the main activities performed by our participants in the TV-set/laptop and the smartphone during multi-screening instances and the uses and gratifications that they reported as related to each of them. 


\section{Table 1. Activities performed during multi-screening instances, and uses and gratifications reported by participants}

\begin{tabular}{|c|c|c|c|c|}
\hline \multicolumn{5}{|c|}{ TV-SET/LAPTOP } \\
\hline Watching... & Instances (\% PT) & Instances (\% ES) & Uses & Gratifications \\
\hline Sports & 8.89 & 26.36 & Entertainment & Entertainment \\
\hline Documentary & 1.67 & 1.55 & Information & $\begin{array}{l}\text { Information } \\
\text { Safety }\end{array}$ \\
\hline Series & 16.11 & 41.09 & Entertainment & Entertainment \\
\hline Soap-opera & 3.89 & 0 & Entertainment & $\begin{array}{c}\text { Entertainment } \\
\text { Safety }\end{array}$ \\
\hline Movie & 46.67 & 20.16 & Entertainment & Entertainment \\
\hline News & 13.89 & 6.2 & Information & $\begin{array}{l}\text { Information } \\
\text { Safety }\end{array}$ \\
\hline Talk-show & 1.67 & 2.33 & $\begin{array}{l}\text { Entertainment } \\
\text { Sociability }\end{array}$ & Entertainment \\
\hline Reality-show & 2.78 & 0.78 & $\begin{array}{l}\text { Entertainment } \\
\text { Sociability }\end{array}$ & $\begin{array}{c}\text { Entertainment } \\
\text { Safety }\end{array}$ \\
\hline Talent-show & 1.11 & 0.78 & $\begin{array}{c}\text { Entertainment } \\
\text { Sociability }\end{array}$ & Entertainment \\
\hline Lifestyle & 3.33 & 0.78 & $\begin{array}{c}\text { Entertainment } \\
\text { Sociability }\end{array}$ & $\begin{array}{c}\text { Entertainment } \\
\text { Sociability }\end{array}$ \\
\hline \multicolumn{5}{|c|}{ SMARTPHONE } \\
\hline Doing... & Instances (\% PT) & Instances (\% ES) & Uses & Gratifications \\
\hline Social networks & 26.67 & 34.11 & $\begin{array}{c}\text { Entertainment } \\
\text { Sociability }\end{array}$ & $\begin{array}{c}\text { Entertainment } \\
\text { Sociability }\end{array}$ \\
\hline Instant Messaging & 28.33 & 43.41 & $\begin{array}{c}\text { Sociability } \\
\text { Entertainment }\end{array}$ & $\begin{array}{c}\text { Sociability } \\
\text { Entertainment }\end{array}$ \\
\hline YouTube & 1.11 & 1.55 & Entertainment & Entertainment \\
\hline Google & 6.11 & 0.78 & Information & $\begin{array}{c}\text { Efficiency } \\
\text { Information }\end{array}$ \\
\hline Blogs & 1.11 & 1.55 & $\begin{array}{l}\text { Entertainment } \\
\text { Information }\end{array}$ & $\begin{array}{c}\text { Entertainment } \\
\text { Information } \\
\text { Sociability }\end{array}$ \\
\hline News & 1.11 & 1.55 & Information & $\begin{array}{l}\text { Information } \\
\text { Safety }\end{array}$ \\
\hline Games & 1.67 & 3.88 & Entertainment & Entertainment \\
\hline Specific App (branded) & 4.44 & 4.65 & $\begin{array}{l}\text { Entertainment } \\
\text { Information }\end{array}$ & $\begin{array}{c}\text { Entertainment } \\
\text { Information } \\
\text { Efficiency }\end{array}$ \\
\hline M-commerce & 0.56 & 0.78 & $\begin{array}{c}\text { Speed } \\
\text { Information }\end{array}$ & $\begin{array}{l}\text { Efficiency } \\
\text { Information }\end{array}$ \\
\hline Utilities & 8.33 & 2.33 & $\begin{array}{c}\text { Spe Speed } \\
\text { Information ed }\end{array}$ & $\begin{array}{l}\text { Efficiency } \\
\text { Information }\end{array}$ \\
\hline Email & 1.67 & 3.88 & Information & Efficiency \\
\hline SMS & 10 & 0 & Sociability & Sociability \\
\hline Voice & 3.33 & 0.78 & Sociability & Sociability \\
\hline Nothing & 5.56 & 0.78 & Speed & Efficiency \\
\hline
\end{tabular}

Note: The three highest percentages are signalled in grey for each case.

Source: Own elaboration. 
Concerning the TV-set or laptop, the most frequently watched content is movies and series, both in Portugal and Spain, followed by news, in Portugal, and sports, in Spain. The uses and gratifications associated with such activities are, as described in previous research about U\&G and TV (Rubin, 1994), entertainment and information.

When engaging with the smartphone, the most common activities are using social media and IM apps, in Portugal and Spain, followed by short message service (SMS), in Portugal, and browsing branded apps, in Spain. However, instead of seeking sociability and sense of belonging (Ho \& Syu, 2010; Quan-Haase, 2010; Serrano-Puche, 2016), our participants have a different take on these communication practices:

If there is something interesting on TV, I don't use it [the smartphone]. The problem is that you almost never find anything interesting on TV. That is why I use the smartphone so much... (ES1)

If I'm watching a series and it gets slow, or nothing is happening, it gets boring. Usually that is when I scroll my social networks feeds, for a few seconds. (...) Instead of zapping, I look for something to do in the smartphone. (PT3)

I guess if a series is having a "dead" moment, I go to Instagram and I am more entertained, but it is also a habit. (PT2)

I was just passing time, a movie was on TV, and I felt like "gossiping" a bit, so I checked what my friends were posting on Instagram and I hung there for a while. (PT13)

These quotes reveal that boredom is one of the main motivations or triggers for engaging in multi-screening behaviour with the smartphone. Our participants feel that the TV content does not have enough quality or rhythm, and talk about "slow" and "dead" moments, not affording enough entertainment. Thus, they resort to the smartphone to extend or enhance the entertainment they were looking for on the TV. This claim from participants is apparently incoherent with their online practices, as instead of consuming entertaining content or playing games, they more often communicate with friends and family in IM apps and browse and interact in social media. They provide two explanations. One of them is the push nature of 
these platforms, as the majority of these interactions are not started by our interviewees. They multi-screen to check and answer messages and notifications that they receive, and they feel the need to read and answer right away. One of the interviewees tries to explain this behaviour:

I don't know... I guess you get used to it. It's like smoking, whenever you have a coffee, you feel the need to smoke... I can't explain it. (ES8)

The other explanation questions one finding from previous research: that "social needs" are a new U\&G category that is characteristic of social media and mobile devices (e.g., Ho \& Syu, 2010; Quan-Haase, 2010) and also the main motivation for multi-screening (e.g., D'heer \& Courtois, 2014; Cameron \& Geidner, 2014; Han \& Lee, 2014; Kramer, Winter, Benninghoff, \& Gallus, 2015; Rossi \& Giglietto, 2016). Our participants report that, when they engage with the smartphone by their own initiative, more than looking for social interaction, sociability or affectivity, they are looking for entertainment. They decided to watch TV looking for entertainment, and when the TV is not providing them the level of stimuli and engagement that they were looking for, they resort to the smartphone to enhance it. As participant ES1 puts it, "The smartphone is like a second TV" (ES1). Thus, they feel entertained by bantering with their friends and browsing through their friends' posts.

Our participants also mention the need of feeling efficient as one of the benefits afforded by the smartphone (e.g., Wang \& Tchernev, 2012; Hwang, Kim, \& Jeong, 2014; Lee \& Shin, 2014; Shin, An, \& Kim, 2015), a need more common among the Portuguese than the Spanish.

One of my justifications for multi-screening is that I want to do all my tasks almost "at the same time." (PT6)

I don't have time to do things separately, so I do them at the same time to be more efficient. (PT15)

I think multi-screening is a good way of avoiding sitting on the couch with the phone in your hand just waiting for an answer, and also of staring at the TV while you're just waiting for the commercials to end, or for the series to pick up some pace. (ES2) 
According to our participants, they do not want to feel that they are wasting time, and they get a sense of accomplishment and self-fulfilment out of performing short and simple tasks while they are obtaining their entertainment from TV, such as conducting searches on Google, using utilities, such as the calendar or the alarm clock, managing photos, checking the weather and the calendar for next day, checking and answering emails.

Our sample registered 11 instances of checking the smartphone without any push stimulus from it or intention to perform any task (10 among the Portuguese and only 1 among the Spanish), just to check if they had missed anything.

We live very accelerated lately. We live in an age when everything is very fast and we want to do everything quickly, and do things all the time. I recognize that I'm not capable of sitting here quietly and not fidgeting with my smartphone. (...) It makes me anxious, I have to do something with my hands. (ES7)

I multi-screen basically to save time. But the benefits I get are not just emotional from conversations I keep, or entertainment, or efficiency. I get a bit of the three. (PT11)

This quote is related to two new categories of uses and gratifications that emerged from the interviews - speed and safety. Speed is mostly associated to the smartphone and to the multi-tasking it affords. It also portrays the irresistibility and even addictive nature of this medium (Levinson, 2004). Safety is often not sought intentionally but obtained from a sense of being informed about current events.

I need my smartphone to know what is going on in the world, no matter what else I am doing. Without it I feel disconnected, isolated. (ES5)

I confess that I watch junk TV from now and then, and I follow celebrities on Instagram. I guess I like to keep up with the trends. Sometimes it makes me feel good about myself, I feel smarter and happier than those people. (PT7)

As the quotes show, this is both afforded by TV content, such as news and documentaries, and by social media accessed via smartphones, which keep users connected to others and up-to-date with events. TV content, 
such as soap operas and reality shows, and social media can also make users feel safer and happier that others portrayed on TV and on social media. Also, keeping up with current events, conversation and even gossip affords a sense of belonging (e.g., Ling, 2004) that also contributes to feeling safe.

Although most research within the U\&G framework has attempted to identify categories of uses and gratifications that are associated to specific media, platforms or content and to hierarchize them, our findings are more consistent with more recent holistic approaches (e.g., Jenkins, 2010; Evans, 2011; D'heer et al., 2012). These argue that users' choices are a result of complex, interdependent and variable combinations of multiple variables, such as medium, platform, content, individual features and contextual features. We argue that multi-screening stems from multi-needs, allows multi-uses and provides multi-gratifications. Instead of looking for unique $U \& G$ attached to media, platforms or content, another direction for $U \& G$ research may be to identify patterns of combinations of media, platforms and content with multiple and often simultaneous U\&G.

Our QCA revealed some patterns, depending on:

A. Degree of interest and immersion regarding the $T V$ content. Viewers who chose a certain content to watch (live or differed) were less likely to multi-screen, as they became immersed in the content they voluntarily chose to watch, were motivated and excited to watch it, were enjoying themselves, and forgot about the smartphone being available and even ignored stimuli from it. On the contrary, viewers who were zapping and were not finding anything interesting or were bored were more likely to multi-screen.

B. Origin of the multi-screening trigger. We observed that the trigger for multi-screening could be internal or external. Internal stimuli were initiatives voluntarily taken by the participants. The most typical case is the participants becoming bored with what they are watching on TV and feeling the need to obtain extra entertainment from the smartphone. There were also cases of participants remembering, by association with the TV content, something that they wanted to do and 
decided to do it right away. Less common was performing activities connected with the TV content. Concerning external stimuli, participants admitted that the sounds or vibrations of their devices were irresistible for them (Levinson, 2004). In these cases, participants did not decide to multi-screen themselves, but were reacting to stimuli from their mobile device. Participants quickly checked notifications from news apps, games and branded apps, but they usually engaged for longer periods in conversations following notifications from social networks, IM messages, and SMS.

C. Affordances of media. Practices and gratifications are shaped by the different affordances (Gibson, 1966; Norman, 1999) of each of the screen-media studied (Wellman, Quan-Haase, Boase, Chen, Hampton, Diaz de Isla, \& Miyata, 2006). The content emerges as more relevant in the case of TV, as entertainment and information are sought and obtained by selecting different types of content. On the contrary, the smartphone affords a contact sense of belonging and efficiency (Katz \& Aakhus, 2002; Ling, 2004), by affording permanent connection to others, access to information, and multi-tasking.

These variables are, of course, interdependent, as, for instance, participants that were immersed in TV content were more likely to ignore stimuli from smartphones, regardless of their affordances.

Our research, thus, presents relevant insights that need to be addressed by future research, preferably using mixed methods, towards a more complex and holistic approach to $U \& G$, to which Affordances Theory may provide a relevant contribution.

\section{Attention distribution}

The notion of multi-screening emphasizes the simultaneous use of different screened media (e.g., Phalen \& Ducey, 2012; Lin, 2013; Van Cauwenberg et al., 2014), as the quotes from our participants exemplify:

If I'm gaming, I use the smartphone and watch TV at the same time. (PT10) 
If I get a voice call, I stop the TV, otherwise I do both things at the same time. (ES2)

They mention some moments of simultaneous use, but only three participants claim that they are able to distribute their attention in an equitable fashion between both devices. The majority of the participants recognize that their attention is focused on one of the devices while the other is present in the background.

Contrary to the initial designation of these practices as "second screening," our participants describe that the smartphone usually preponderates over the TV-set.

It's impossible to do both things at the same time literally, right? When I'm using on [of the devices], the other is left to the side. (ES3)

I don't think it is the TV that triggers our activities in other devices, but I don't think it is the other way around either. I believe there is a correlation between both. (PT12)

This is due, according to our participants, to the push nature of the smartphone, as its sounds, light and vibration "demand" attention (Levinson, 2001) and usually superimpose to other activities (Ling, 2004). As participant ES3 admits, "Any vibration from the smartphone, I have to look at it” (ES3). Other participants add:

If I'm having a conversation with someone, an engaging conversation, I stop paying attention to the TV. Sometimes I intercalate between the conversation and the series. (ES9)

I was "Whatsapping" and sometimes I took a look at the football match to see if it was interesting. But when there is something interesting on TV, the smartphone goes to the background and I only check it during commercial breaks. (ES7)

Even when they are immersed in watching TV, it is difficult to ignore push stimuli from the smartphone. It is also noteworthy that some of the participants felt the urge of checking their smartphone without any external trigger or internal motivation. 
Our participants acknowledge the "irresistibility" of the smartphone - it has a greater ability to get attention and foster engagement (e.g., Cameron \& Geidner, 2014; Van Cauwenberge et al., 2014; McCreery \& Krugman, 2015), but they perceive advantages and disadvantages to it.

When I am doing two things at the same time, one is a task and the other is a distraction. Sometimes, it is even helpful, but it is still a distraction. (ES3)

It's a plus [the smartphone]. If you're watching something and you want more, the smartphone can give you that extra information, or entertainment. But it also distracts me a lot. I want not to pay attention to it, but I can't be without it. I think "I'm not going to touch it" and even then I'm distracted because I am thinking about what I could be doing with it, or about what is happening that I don't know yet. (ES13)

Thus, distracted viewing (Smith \& Boyles, 2012) leads to distraction, often unintended by our participants, but difficult to avoid.

The smartphone also becomes the focus of attention due to the lack of engagement afforded by the TV. Thus, when the TV is not interesting enough, it is easy to turn to the smartphone as a solution for enhancing the entertainment they are looking for.

In my opinion, it's not the mobile devices that call our attention. I only use the smartphone when what I'm watching on TV is not interesting enough. (PT10)

\section{Conclusion}

With our exploratory study, we have addressed some of the ongoing debates about multi-screening and identified insights and trends that are important contributions in pointing directions for future research.

Concerning the variety of activities that multi-screening may entail, our research calls for a closer look at the concept of social $\mathrm{TV}$, as social interaction online is the most common activity performed via mobile devices during TV-viewing, but, in our sample, it was usually unrelated to the TV content being watched, and it more often afforded entertainment as 
gratification, instead of sociability. The exception was during live TV broadcasting, when users commented on social networks and instant messaging about TV content being watched and reported, obtaining a sense of belonging from this practice. Thus, further exploring the differences between live and differed TV emissions and their effects on multi-screening behaviour is a relevant endeavour.

Regarding the motivations for multi-screening, participant PT2 provides a summary:

\begin{abstract}
I believe that we multi-screen when we get a message and our phone vibrates; when we are watching something boring that is not capturing our attention and we grab our phone; or simply when we remember that we haven't checked Instagram for a bit and we decide to do it while we are watching TV. (PT2)
\end{abstract}

Thus, our findings challenge the preponderance of the "social TV" strand of research in the field because, in spite of the activities performed on smartphones being related to social interaction, our participants turn to them as a source of entertainment, instead of social gratifications (e.g., Ho \& Syu, 2010; Quan-Haase, 2010; D'heer \& Courtois, 2014; Cameron \& Geidner, 2014; Han \& Lee, 2014; Kramer et al., 2015). They do so when the TV is not being entertaining enough. On the contrary, our results corroborate that efficiency and self-fulfilment are gratifications deriving from multi-screening (e.g., Wang \& Tchernev, 2012; Hwang, et al., 2014; Lee \& Shin, 2014).

In addition, in the face of the multiplicity of combinations and articulations of TV genres and smartphone-mediated activities, we spotted consistent patterns according to the degree of interest and immersion regarding the TV content, the origin of the multi-screening trigger and the affordances of both media. These patterns often involved more than one use and more than one gratification, leading to the argument that a phenomenon like multi-screening is inherently triggered by multi-needs and affords multi-gratifications. In future research, U\&G can move towards more complex and holistic approaches (Jenkins, 2010; Evans, 2011; D'heer et al., 2012), based on pattern recognition and complexity models. Digital big 
data pose ethical challenges, as their collection can be intrusive and invasive, but they may also be key tools for further researching multiple uses and gratifications patterns and profiles.

About attention distribution, our study questions the second screening approach, as the smartphone preponderates over the TV and attention distribution is more often sequential and intercalary than simultaneous. Moreover, we found an apparent paradox that needs clarification: The smartphone is often perceived as a distraction relatively to other activities, but irresistibly becomes the main focus of attention nonetheless.

Multi-screening is an emergent but fast growing and fast changing practice, evolving along with the technologies that mediate it. The challenge for research in the near future is to keep up with the fast pace of the phenomena it studies and to uncover all of its complexity.

\section{References}

Boyatzis, R. (1998). Transforming qualitative information: Thematic analysis and code development. London, UK: Sage.

Brinkman, S., \& Kvale, S. (2014). InterViews: Learning the craft of qualitative research interviewing. London, UK: Sage.

Buschow, C., Schneider, B., \& Ueberheide, S. (2014). Tweeting television: Exploring communication activities on Twitter while watching TV. Communications - The European Journal of Communications Research, 39(2), 129-149. DOI: https://doi.org/10.1515/commun-2014-0009

Cameron, J., \& Geidner, N. (2014). Something old, something new, something borrowed from something blue: Experiments on dual ViewingTV and Twitter. Journal of Broadcasting \& Electronic Media, 58(3), 400-419. DOI: https://doi.org/10.1080/08838151.20 14.935852 
Chun, H., Lee, H., \& Kim, D. (2012). The integrated model of smartphone adoption: Hedonic and utilitarian value perceptions of smartphones among Korean college students. Cyberpsychology, Behavior and Social Networking, 15(9), 473-479. DOI: https://doi. org/10.1089/cyber.2012.0140

Cooper, R., \& Tang, T. (2009). Predicting audience exposure to television in today's media environment: An empirical integration of active-audience and structural theories. Journal of Broadcasting \& Electronic Media, 53(3), 400-418. DOI: https://doi. org/10.1080/08838150903102204

D’heer, E., Courtois, C., \& Paulussen, S. (2012). Everyday life in (front of) the screen: The consumption of multiple screen technologies in the living room context. EuroITV'12. Proceedings of the 10th European Conference on Interactive TV and Video (pp. 195-198) July 4-6, Berlin, Germany. Retrieved from https://dl.acm.org/citation.cfm?id=2325654

D'heer, E., \& Courtois, C. (2014). The changing dynamics of television consumption in the multimedia living room. Convergence: The International Journal of Research into New Media Technologies, 22(1), 3-17. DOI: https://doi.org/10.1177/1354856514543451

D'heer, E., \& Verdegem, P. (2015). What social media data mean for audience studies: A multi-dimensional investigation of Twitter use during a current affairs TV programme. Information, Communication \& Society, 18(2), 221-234. DOI: https://doi.org/10.1080/ 1369118X.2014.952318

Dias, P. (2008). O telemóvel e o quotidiano [The mobile phone and daily life]. Lisbon, Portugal: Paulus.

Dias, P. (2016). Motivations for multi-screening: An exploratory study on motivations and gratifications. European Journal of Communication, 31(6), 678-693. DOI: https://doi.org/10.1177/0267323116674111

26 Multi-needs for Multi-screening: Practices, Motivations, and Attention Distribution - Patrícia Dias and other 
Dias, P. \& Teixeira-Botelho, I. (2016). Multi-screening: Emergent practices, motivations and expectations. Redes.com, 13, 273-292. Retrieved from http://revista-redes.hospedagemdesites.ws/index.php/revista-redes/article/view/380

Ducheneaut, N., Moore, R., \& Oehlberg, L. (2008). Social TV: Designing for distributed, sociable television viewing. International Journal of Human-Computer Interaction, 24(2), 136-154. DOI: https://doi. org/10.1080/10447310701821426

Dutta-Bergman, M. J. (2004). Complementarity in consumption of news types across traditional and news media. Journal of Broadcasting \& Electronic Media, 48(1), 41-60. DOI: https://doi.org/10.1207/ s15506878jobem4801_3

Evans, E. (2011). Transmedia television: Audiences, new media and daily life. London, UK: Routledge.

Fortunati, L. (2002). The mobile phone: Towards new categories and social relations. Information, Communication \& Society, 5(4), 513528. DOI: https://doi.org/10.1080/13691180208538803

Ferguson, D. A., \& Perse, E. M. (2000). The World Wide Web as a functional alternative to television. Journal of Broadcasting \& Electronic Media, 44(2), 155-174. DOI: https://doi.org/10.1207/ s15506878jobem4402_1

Gibson, J. (1966). The senses considered as perceptual systems. London, UK: Allen \& Unwin.

Giglietto, F., \& Selva, D. (2014). Second screen and participation: A content analysis on a full season dataset of tweets. Journal of Communication, 64(2), 260-277.DOI: https://doi.org/10.1111/jcom.12085

Gil de Zuñiga, H. G., Garcia-Perdomo, V., \& McGregor, S. (2015). What is second screening? Exploring motivations of second screen use 
and its effect on online political participation. Journal of Communication, 65, 793-815. DOI: http://doi.org/10.1111/jcom.12174

Google. (2012). The new multi-screen world: Understanding cross-platform computer behavior. Google think insights. Retrieved from https: // www.thinkwithgoogle.com/advertising-channels/mobile-marketing/the-new-multi-screen-world-study/

Guerrero, E., Diego, P., \& Kimber, D. (2017). Hooked on lit screens / Enganchados a las pantallas. El profesional de la información, 26(6), pp. 1108-1118. Retrieved from http://www.elprofesionaldelainformacion.com/contenidos/2017/nov/10.pdf

Hammersly, M., \& Atkinson, P. (2007). Ethnography: Principles in practice. London, UK: Routledge.

Han, E., \& Lee, S.W. (2014). Motivations for the complimentary use of text-based media during linear TV-viewing: An exploratory study. Computers in Human Behavior, 32, 235-243. DOI: https://doi. org/10.1016/j.chb.2013.12.015

Haridakis, P., \& Hanson, G. (2009). Social interaction and co-viewing with YouTube: Blending mass communication reception and social connection. Journal of Broadcasting \& Electronic Media, 53(2). DOI: https://doi.org/10.1080/08838150902908270

Ho, H.Y., \& Syu, L.Y. (2010). Uses and gratifications of mobile application users. Proceedings of 2010 International Conference on Electronics and Information Engineering, VI, 315-319.

Holmes, M., Josephson, S., \& Carney, R. (2012). Visual attention to TV programs with a second screen application. ETRA 2012. Proceedings of the Symposium on Eye Tracking Research and Applications (pp. 397-400), Santa Barbara, CA. 
Hwang, Y., Kim, H., \& Jeong, S. (2014). Why do media users multitask?: Motives for general, medium-specific, and content-specific types of multitasking. Computers in Human Behavior, 36, 542-548. DOI: https://doi.org/10.1016/j.chb.2014.04.040

Jenkins, H. (2010). Transmedia storytelling and entertainment: An annotated syllabus. Continuum - Journal of Media and Cultural Studies, 24(6), 943-958. DOI: https://doi.org/10.1080/10304312. 2010.510599

Jensen, M. (2016). The emergence of second screen gatekeeping. Digital Journalism, 4(3), 321-338. DOI: https: //doi.org/10.1080/2167 0811.2015 .1054408

Joison, A. N. (2008). Looking at, looking up or keeping up with people? Motives and use of Facebook. Conference on Human Factors in Computer Systems (CHI), 26th annual SIGGCHI conference, Florence, Italy.

Katz, E., Blumler, J. G., \& Gurevitch, M. (1974). Utilization of mass communication by the individual. In J. G. Blumler \& E. Katz (Eds.), The uses of mass communications: Current perspectives on gratifications research (pp. 19-32). Beverly Hills, CA: Sage.

Katz, J. (2006). Machines that become us: The social context of personal communication Technology. New York, NY: Transaction Publishers.

Katz, J., \& Aakhus, M. (2002). Perpetual contact: Mobile communication, private talk, public performance. Cambridge, MA: Cambridge University Press.

Kim, S. J. (2014). A repertoire approach to cross-platform media use behavior. New Media \& Society, 18(3), 353-372. DOI: https://doi. org/10.1177/1461444814543162 
Kramer, N., Winter, S., Benninghoff, B., \& Gallus, C. (2015). How "social” is social TV? The influence of social motives and expected outcomes on the use of social TV applications. Computers in Human Behavior, 51,255-262. DOI: https://doi.org/10.1016/j.chb.2015.05.005

Lee, A. (2013). News audiences revisited: Theorizing the link between audience motivations and news consumption. Journal of Broadcasting \& Electronic Media, 57, 300-317. DOI: https://doi.org/10.10 80/08838151.2013.816712

Lee, J., \& Shin, D. (2014). The relationship between human and smart TVs based on emotion recognition in HCI. Lecture Notes in Computer Science, 8582, 652-667. DOI: https://doi.org/10.1007/9783-319-09147-1_47

Levinson, P. (2004). Cellphone: The story of the world's most mobile medium and how it has transformed everything! New York, NY: Palgrave.

Lin, T. (2013). Convergence and regulation of multi-screen television: The Singapore experience. Telecommunications Policy, 37(8), 673-685. DOI: https://doi.org/10.1016/j.telpol.2013.04.011

Ling, R. (2004). The mobile connection: The cell phone's impact on society. San Francisco, CA: Morgan Kaufmann.

Lochrie, M., \& Coulton, P. (2012). Sharing the viewing experience through second screens. Proceedings of the 10th European Conference on Interactive TV and Video (pp. 199-202). Berlin, Germany.

Lombard, M.,Ditton, T. B., Grabe,M.E., \& Reich, R.D.(1997). The role of screen size in viewer responses to television fare. Communication Reports, 10, 95-106. DOI: https://doi.org/10.1080/08934219709367663

Maxwell,J. (1996). Qualitative research design: An interactive approach. London, UK: Sage. 
McCreery, S. P., \& Krugman, D. M. (2015). TV and the iPad: How the tablet is redefining the way we watch. Journal of Broadcasting \& Electronic Media, 59(4), 620-639. DOI: https://doi.org/10.1080/0 8838151.2015 .1093483

McNiven, M. D., Krugman, D., \& Tinkham, S. F. (2012). The big picture for large-screen television viewing. Journal of Advertising Research, 52, 421-432. DOI: https://doi.org/10.2501/JAR-52-4-421-432

Microsoft. (2013). Connected experiences, cross-screen engagement: Multiscreen pathways reveal new opportunities for marketers to reach and engage consumers. Retrieved from https://www.yumpu.com/en/ document/read/17349623/cross-screen-engagement-research-report-microsoft-advertising

Nandakumar, A. \& Murray, J. (2014). Companion apps for long arc TV series: supporting new viewers in complex storyworlds with tightly synchronized context-sensitive annotations, TVX'14 - Proceedings of the ACM International Conference on Interactive Experiences for $T V$ and Online Video (pp. 3-10).

Norman, D. (1999). Affordance, conventions and design. Interactions, 6(3), 38-43. DOI: http://doi.org/10.1145/301153.301168

Nielsen (2015). Screen wars: The battle for eye space in a TV-everywhere world. Newswire Nielsen. Retrieved from https://www.nielsen. com/us/en/insights/report/2015/screen-wars-the-battle-foreye-space-in-a-tv-everywhere-world/

Pérez-Tornero, J. (2008). La sociedad multipantallas: Retos para la alfabetización mediática. Comunicar, 31(16), 15-25. DOI: https://doi. org/10.3916/c31-2008-01-002

Phalen, P. F., \& Ducey, R. V. (2012). Audience behavior in the multi-screen "video-verse". International Journal on Media Management, 14(2), 141-156. DOI: https://doi.org/10.1080/14241277.2012.657811 
Quan-Haase, A., \& Young, A. (2010). Uses and gratifications of social media: A comparison of Facebook and Instant Messaging. Bulletin of Science Technology and Society, 30(5), 350-361. DOI: https://doi. org/10.1177/0270467610380009

Ragin, C. (2014). The comparative method: Moving beyond qualitative and quantitative strategies. Oakland, CA: University of California Press.

Reeves, B., Lang, A., Kim, E. Y., \& Tatar, D. (1999). The effects of screen size and message content on attention and arousal. Media Psychology, 1,49-67.DOI: https://doi.org/10.1207/s1532785xmep0101_4

Rossi, L., \& Giglietto, F., (2016). Twitter use during TV: A full-season analysis of \#serviziopubblico. Journal of Broadcasting \& Electronic Media, 60(2), 331-346. DOI: https://doi.org/10.1080/08838151. 2016.1164162

Rubin, A. M. (1994). Media uses and effects: a uses and gratifications perspective. In Bryant, J., Zillman, D. (Eds.), Media effects: Advances in theory and research (pp. 417-436). Lawrence Hillsdale, NJ: Lawrence Erlbaum Associates.

Serrano-Puche, J. (2015). Emociones en el uso de la tecnología: un análisis de las investigaciones sobre teléfonos móviles. Observatorio (OBS), 9(4), 101-112. Retrieved from https://www.academia. edu/19721736/Emociones_en_el_uso_de_la_tecnología_un_ análisis_de_las_investigaciones_sobre_teléfonos_móviles

Serrano-Puche, J. (2016). Internet and emotions: New trends in an emerging field of research. Comunicar, 46, 19-26. DOI: http://doi. org/10.3916/C46-2016-02

Shin, D. H. (2013). N-Screen: How multi-screening will impact diffusion and policy? Information, Communication \& Society, 16(6), 918944. DOI: https://doi.org/10.1080/1369118X.2012.744073 
Shin, D., Shin, Y., Choo, H., \& Beom, K. (2011). Smartphones as smart pedagogical tools: Implications for smartphones as u-learning devices. Computers in Human Behavior, 27(6), 2207-2214. DOI: https:// doi.org/10.1016/j.chb.2011.06.017

Shin, D. H., An, H., \& Kim, J. H. (2015). How the second screens change the way people interact and learn: The effects of second screen use on information processing. Interactive Learning Environments, 23(5), 1-22. DOI: https://doi.org/10.1080/10494820.2015.1076851

Simons, N. (2015). TV drama as a social experience: An empirical investigation of the social dimensions of watching TV drama in the age of non-linear television. Communications - The European Journal of Communications Research, 40(2), 219-236. DOI: https://doi. org/10.1515/commun-2015-0005

Smith, A., \& Boyles, J.L. (2012). The rise of the "connected viewer" (Pew internet \& American life project). Pew Research Center. Retrieved from https://www.pewinternet.org/2012/07/17/the-rise-of-theconnected-viewer/

Vaccari, C., Chadwick, A., \& O'Loughlin, B. (2015). Dual screening the political: Media events, social media, and citizen engagement. Journal of Communication, 65(6), 1041-1061. DOI: https://doi. org $/ 10.1111 /$ jcom. 12187

Van Cauwenberge, A., Schaap, G., \& Van Roy, R. (2014). “TV no longer commands our full attention": Effects of second-screen viewing and task relevance on cognitive load and learning from news. Computers in Human Behavior, 38, 100-109. DOI: https://doi. org/10.1016/j.chb.2014.05.021

Van Cauwenberge, A., d'Haenens, L., \& Beetjes, H. (2015). How to take advantage of tablet computers: Effects of news structure on recall and comprehension. Communications - The European Journal 
of Communications Research, 40(4), 425-446. DOI: https://doi. org/10.1515/commun-2015-0020

Vergeer, M., \& Franses, P. H. (2016). Live audience responses to live televised election debates: Time series analysis of issue salience and party salience on audience behavior. Information, Communication \& Society, 19(10), 1390-1410. DOI: https://doi.org/10.1080/1 369118X.2015.1093526

Wang, Z., \& Tchernev, J. M. (2012). The "myth" of media multitasking: Reciprocal dynamics of media multitasking, personal needs, and gratifications. Journal of Communication, 62(3), 493-513. DOI: https://doi.org/10.1111/j.1460-2466.2012.01641.x

Weeks, B. E., \& Holbert, R. L. (2013). Predicting dissemination of news content in social media a focus on reception, friending, and partisanship. Journalism \& Mass Communication Quarterly, 90(2), 212 232. DOI: https://doi.org/10.1177/1077699013482906

Wei, R. (2008). Motivations for using the mobile phone for mass communication and entertainment. Telematics \& Informatics, 25, 36-46. DOI: https://doi.org/10.1016/j.tele.2006.03.001

Wellman, B., Quan-Haase, A., Boase, J., Chen, W., Hampton, K., Diaz de Isla, I. \& Miyata, K. (2006). The Social Affordances of the Internet for networked individualism, Journal of Computer Mediated Communication, 8(3). DOI: https://doi.org/10.1111/j.1083-6101.2003. tb00216.x 